Pamiętnik Literacki 2012, 4, s. 19-26
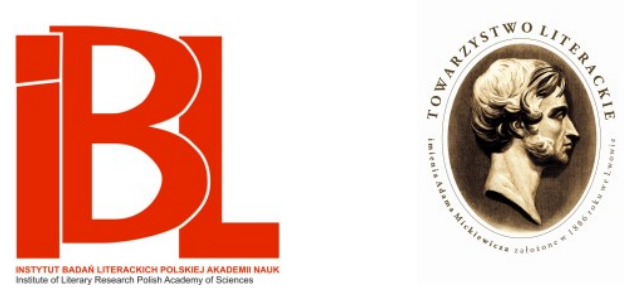

\title{
Pani Bovary w tropikach: bowaryzm jako
} zjawisko (post)kolonialne

\author{
Zuzanna Krasnopolska
}




\title{
PANI BOVARY W TROPIKACH: BOWARYZM JAKO ZJAWISKO (POST)KOLONIALNE
}

\author{
To natrętne serce wciąż mi zapomnieć nie daje, \\ Że mu obcy mój język, moje garnitury, \\ Że te europejskie moje obyczaje \\ I te czucia tutejsze są mu jak tortury. \\ Czy ogarnie ktoś ogrom mojej desperacji, \\ Mojej niewyrażalnej boleści i żalu, \\ Że mi przyszło słowami, co rodem są z Francji, \\ Obłaskawiać to serce, które mam z Senegalu ${ }^{1}$.
}

Emma Bovary to pierwsza, obok Salomei, kobieca postać literacka, której francuskie wydawnictwo „Autrement” poświęciło oddzielny tom w serii „Figures Mythiques"2. Jej nieobecność w Dictionnaire des mythes littéraires (1988) nie przesądza o niczym, brak nadrobiła z nawiązką późniejsza publikacja Dictionnaire des mythes féminins ${ }^{3}$. Zastanówmy się jednak nad źródłami mityczności bohaterki Flauberta. Podobnie jak Yvan Leclerc, dyrektor Centre de Flaubert w Rouen, możemy uważać, że brak większości nazwisk autorów książek i tytułów lektur ${ }^{4}$, które ukształtowały Emmę, wskazuje na zamierzoną przez twórcę bezosobowość dzieła, co prowadzi do oderwania go od tradycji powieści, a ponadto do mityzacji ${ }^{5}$. Natomiast zgodnie z definicją Claude'a Lévi-Straussa:

[Mity] nie mają autora: od chwili, w której zostaną uznane za mity, nie istnieją w oderwaniu od tradycji, niezależnie od ich prawdziwego pochodzenia. Gdy opowiadamy mit, indywi-

1 L. L a le a u, Zdrada. W zb.: Antologia poezji afrykańskiej. Red. W. Leopold, Z. Stolarek. Warszawa 1974, s. 42 (przeł. Z. S t o l a r e k).

2 Inni mityczni bohaterowie literaccy w tej serii to: Alicja w Krainie Czarów, Antygona, Carmen, Drakula, Frankenstein, Józef K., Judasz, Kasandra, Lancelot, Lolita, Lord Jim, doktor Jekyll i pan Hyde, Philip Marlowe, Robinson Kruzoe.

3 Dictionnaire des mythes féminins. Red. P. B r u n e 1. Paris 2002.

4 Autorzy wymienieni z nazwiska to Balzak, Bernardin de Saint-Pierre, Chateaubriand, Frayssinous, Hugo, Lamartine, Scott, Sand oraz Sue. Należy jednak pamiętać, że Emma czytała książki wybiórczo, „otwierała je, odkładała, brała się do innych” (G. F l a u b e r t, Pani Bovary. Z obyczajów prowincji. Przeł., posł. R. En g e 1 k in g. Gdańsk 2005, s. 124), z pewnością nie znała wszystkich dzieł wymienionych pisarzy, a o jej słabości do romansów, gdzie tyle „łez i pocałunków, łódek w świetle księżyca, słowików w zaroślach, gentlemanów walecznych jak lwy i potulnych jak baranki, pełnych nieziemskich cnót [...]" (ibidem, s. 39-40), powszechnie wiadomo.

5 I. L e cle rc, Comment une petite femme devient mythique. W zb.: Emma Bovary. Red. A. B u is in e. Paris 1997, s. 21. 
dualni słuchacze otrzymują wiadomość pochodzącą właściwie znikąd; oto dlaczego przyznajemy mitowi pochodzenie nadnaturalne ${ }^{6}$.

Pani Bovary stała się zatem figurą mityczną, a bowaryzm - fenomenem występującym na szeroką skalę. Przyjrzyjmy się mu jednak bliżej. Przede wszystkim należy pamiętać, że Jules de Gaultier (1858-1942) ukuł termin „bowaryzm”" w celu scharakteryzowania swojej filozofii tylko w o p a r c i u o Flauberta, a nie d z i ęk i niemu: powieść francuskiego pisarza posłużyła mu za interesujący przykład i inspirację do sformułowania własnej idei. Po drugie, bowaryzm nie jest wyłącznie zjawiskiem literackim. Gaultier użył nazwiska bohaterki do przedstawienia swojej wizji procesu identyfikacji człowieka, kreacji istoty ludzkiej jako mozaiki złożonej z elementów zapożyczonych bądź skopiowanych i wywodzących się z różnych źródeł. W dziele Le Bovarysme. La psychologie dans l'œuvre de Flaubert (1892) francuski filozof thumaczy, że bowaryzm to podstawowa, uniwersalna i powszechna ,zdolność dana człowiekowi do postrzegania siebie innym, niż się jest”8. Emma Bovary uosabia jedynie patologiczną odmianę bowaryzmu, definiowaną jako wada osobowości, cecha regresywna, skłonność odznaczająca się kłamstwem i wyraźnym rozdwojeniem charakteru czy wręcz elementami trawestacji i kameleonizmu.

Bowaryzm funkcjonuje wszakże nie tylko w odniesieniu do jednostki, lecz także na poziomie zbiorowości społecznych i kulturalnych. Gaultier precyzuje:

dla każdego rodzaju grupy lub zbiorowości bowaryzm występuje w sytuacji, kiedy pewna liczba osób, wchodzących w ich skład, przeżywa fascynację obcym zwyczajem, zamiast poddać się sugestii zwyczaju przynależnego własnej społeczności ${ }^{9}$.

Bowaryzm zbiorowy jest zatem w pewnym sensie zbliżony do teorii narodów jako „wspólnot wyobrażonych” Benedicta Andersona ${ }^{10}$, subiektywnych kreacji zbudowanych na zespołach przedstawień: wyobrażonych, ,ponieważ członkowie nawet najmniej licznego narodu nigdy nie znają większości swych rodaków, nie spotykają ich, nic nawet o nich nie wiedzą, a mimo to pielęgnują w umyśle obraz wspólnoty" ${ }^{11}$.

Bowaryzm odnoszący się do życia zbiorowości ma swoje wady i zalety. Z jednej strony, jest etapem w procesie ewolucji i doboru naturalnego, etapem w edu-

${ }^{6}$ C. Lé v i - S tra u s s, Mythologies. Le Cru et le Cuit. Paris 1964, s. 26.

${ }^{7}$ Najnowsze dostępne edycje i opracowania teorii bowaryzmu to J. de Gaultie r: Le Bovarysme. Suivi d'une étude de P. B u v i k Le Principe bovarique. Paris-Sorbonne 2006; Le Bovarysme. La psychologie dans l'œuvre de Flaubert. Annoté et présenté par D. P h il i p p o t. Suivi de neuf études réunies et coordoées par P. B uvik. Paris 2008.

${ }^{8} \mathrm{G}$ a ulti e r, Le Bovarysme, s. 10.

9 Ibidem, s. 51.

${ }^{10} \mathrm{~B}$. A n d e rs o n, Wspólnoty wyobrażone. Rozważania o źródtach i rozprzestrzenianiu się nacjonalizmu. Przeł. S. A m s t e r d a m s k i. Kraków 1997. Teorię tę przytacza zresztą D. G u e d j i $\mathrm{w}$ jednym $\mathrm{z}$ esejów zawartych $\mathrm{w}$ tomie Le Bovarysme. La psychologie dans l'œuvre de Flaubert (s. 316).

11 A n d e r s o n, op. cit., s. 19. Dla naszej dyskusji interesujący jest również przypis autora do tego zdania: „Por. Seton-Watson, Nations and States, cyt. wyd. [tj. Westview Press, Boulder, Colorado 1977], s. 5: »Tyle tylko potrafię powiedzieć, że naród istnieje, kiedy znacząca liczba ludzi traktuje samych siebie jako jego członków lub też zachowuje się tak, jakby nimi była«. Określenie »traktuje siebie« można rozumieć jako »wyobraża sobie siebie«" (ibidem, s. 19, przypis 9) - a stąd już blisko do bowarystycznego ,postrzegania siebie innym, niż się jest”. 
kacji i rozwoju. Z drugiej, poddanie się fascynacji obcym zwyczajem, obcym w sensie: nie przynależącym do rodzimej tradycji, może doprowadzić do utraty tożsamości i jedności. Jako przykłady bowaryzmu pozytywnego i negatywnego Gaultier wymienia kulturę japońską, opartą na silnie rozwiniętej umiejętności asymilacji, która jest motorem rozwoju ich cywilizacji, oraz chińską, hermetyczną i skostniałą. Jak dowodzi dalej badacz, imitacja włoskiego renesansu we Francji przyniosła wybitne rezultaty, natomiast silny wpływ kultury europejskiej w Amerykach Północnej i Południowej doprowadził do wyparcia tradycji tubylczych.

Francuski antropolog, Arnold van Gennep (1873-1957), zajmujący się przede wszystkim zagadnieniem obrzędów przejścia (Obrzędy przejścia, 1909), w eseju O kilku przypadkach bowaryzmu zbiorowego ${ }^{12}$ podąża tropem narzucania własnej kultury podległym społecznościom. Zmiany zachodzące w różnych grupach (od plemion do narodów) i na wszystkich poziomach organizacji życia (od religii po język) obserwuje na dwóch płaszczyznach: inwencji indywidualnej i asymilacji zbiorowej. Antropolog podtrzymuje rozróżnienie bowaryzmu na pozytywny i negatywny: „,bowaryzm stanowi jednocześnie siłę, jak i słabość” ${ }^{13}$. Potencjał i żywotność ludów tubylczych tkwią w postrzeganiu siebie takimi, jakimi są; zastój zaś cywilizacji liberyjskiej jest wynikiem wyobrażania i pragnienia siebie innymi aż po ,wykorzenienie” i utratę własnej przeszłości.

Van Gennep podkreśla, że iluzja bycia innym i lepszym, czyli liberyjski bowaryzm zbiorowy, rzuca światło na element częstokroć zaniedbywany, ale niezwykle ważny w dyskusji o kolonializmie, czyli na czynnik psychologiczny. Przystosowanie się lub jego brak oraz związki między jednostkami determinują szansę przeżycia i ewolucję społeczności. Zderzenie domniemanej wyższości potomków niewolników amerykańskich z wymuszoną niższością ,ich pogańskich braci” zahamowuje rozwój kultury i prowadzi do stopniowej utraty jedności, a co za tym idzie, do utraty tożsamości.

Esej van Gennepa, pełnoprawnego mieszkańca Starego Kontynentu, przedstawia jedynie punkt widzenia kolonizatora. Brak w nim perspektywy drugiej strony dialogu, tj. opinii badaczy wywodzących się z kręgu kultur skolonizowanych. Przyjrzyjmy się zatem, jak o zaistniałej sytuacji piszą reprezentanci kolonii, czyli jak, innymi słowy: „the empire writes back [imperium odpisuje]” ${ }^{14}$.

W swojej analizie van Gennep przywołuje bunt na Haiti jako przykład niebezpiecznej i błędnej drogi do uwolnienia się od szkodliwego bowaryzmu i odtworzenia narodu. Haitański badacz Jean Price-Mars (1876-1969) poświęcił frankofilskiemu bowaryzmowi ${ }^{15}$ swojej wyspy książkę zatytułowaną Ainsi parla l'oncle $(1928)^{16}$, co można by przetłumaczyć jako „Tako rzecze wuj”. Koncentruje się

12 A. van G e n ne p, De quelques cas de bovarysme collectif. „Mércure de France” 1908, $\mathrm{nr}$ z 16 V. Zob. przekład tego eseju w niniejszym zeszycie.

13 Ibidem, s. 239.

${ }^{14}$ Nawiązuję do tytułu głośnej książki poświęconej postkolonializmowi: B. A s h c r o ft, G. Griffith s, H. Tiffi n, The Empire Writes Back: Theory and Practice in Postcolonial Literature. London 1989.

15 Autorstwo pojęcia bowaryzmu zbiorowego jest niekiedy przypisywane J. Price-Marsowi, m.in. w książce L. M. P o r te r a A Gustave Flaubert Encyclopedia (Westport 2001, s. 64).

${ }_{16}$ J. Price-Mars, Ainsi parla l'oncle. Essais d'ethnographie. New York 1954. Dalej do 
w niej na dyskusji nad antropologią i etnografią wyspy, analizę bowaryzmu traktując zgoła marginalnie.

Ten typ bowaryzmu zbiorowego objawia się poprzez skłonność Haitańczyków do zapominania o własnych korzeniach, ignorowania tradycji i zwyczajów, na rzecz bezkrytycznej identyfikacji z wzorcami kulturowymi płynącymi z Europy, jakby wzór Starego Świata był jedynym godnym naśladowania ${ }^{17}$. Tendencję tę można zaobserwować głównie wśród przedstawicieli miejscowej inteligencji, która odnosi się z wyższością i niechęcią do niższych, mniej wykształconych warstw społecznych:

To zadziwiające, że ten naród, który miał, jeśli nie najpiękniejszą, to z pewnością najbardziej porywającą, najbardziej wzruszającą historię na świecie - historię przeniesienia rasy ludzkiej na obcy teren w najgorsze warunki biologiczne - odczuwa z trudem skrywaną niechęć, a niekiedy wręcz wstyd, słuchając o swojej dalekiej przeszłości. [P-M 9]

Takiego rodzaju sytuacja i stosunki społeczne prowadzą do deprecjacji słów „Murzyn” i „czarny”. W ten sposób nazywanie mieszkańca Haiti „Afrykaninem” staje się ,najbardziej upokarzającym określeniem, jakim możemy nazwać Haitańczyka" (P-M 10).

W takiej atmosferze braku zainteresowania i poszanowania tradycji rodzi się literatura narodowa. Mimo bogactwa baśni, legend, podań i wierzeń rdzenna kultura jest ignorowana. W zamian pisarze przekształcają na własną modłę literaturę francuską, tworząc „,płaskie i służalcze imitacje” (P-M 10). Powszechne użycie języka francuskiego prowadzi do ,rodzaju psychozy mniej lub bardziej poważnej - gadatliwości" ${ }^{18}$, typowej dla kolejnych pokolen Haitańczyków, którzy przez lata opierali swoją edukację na bezmyślnym powtarzaniu i uczeniu się na pamięć oryginałów francuskich. Price-Mars podaje jako znamienny przykład Georges'a Sylvaina i jego zbiór baśni Cric-Crac ${ }^{19}$ : chwali go za spisanie ich w języku kreolskim, ale w gruncie rzeczy surowo gani za przetłumaczenie bajek Jeana de La Fontaine'a, uznając to za zaprzepaszczenie szansy na stworzenie wiekopomnego dzieła ugruntowującego folklor haitański.

pozycji tej odsyłam skrótem P-M. Prócz tego stosuję skrót F = F. F a n o n, Peau noire, masques blancs. Paris 1952. Liczby po skrótach oznaczają stronice.

17 Podobne spostrzeżenia na temat Haiti poczynił R. O ri zi o w książce Zaginione białe plemiona. Podróż w poszukiwaniu zapomnianych mniejszości (Wstęp R. Ka p u śc iń s ki. Przeł. J. U g n i e w s k a, M. S a 1 w a. Warszawa 2009, s. 184): „Fort, w swoim czasie uznawany za ósmy cud świata, został wzniesiony na szczycie góry tak wysoko, by zawsze - przynajmniej częściowo - tonął w chmurach. Niewiele poniżej stał królewski pałac Sans-Souci, noszący tę samą nazwę, co pałac Fryderyka Wielkiego w Poczdamie. Miał to być Wersal Nowego Świata, zaprojektowany z takim luksusem, jakiego Antyle wcześniej nie znały. Każdy szlachcic na Haiti, będący często potomkiem jakiegoś afrykańskiego wodza, musiał stawać na dworze monarchy zgodnie z literą niezmiernie skomplikowanego protokołu: miał mieć na sobie specjalny mundur arystokracji, buty z czerwonego marokinu i ze złotą sprzączką, kapelusz z pióropuszem (niebieskie pióra dla baronów, czerwone dla książąt itd.), aksamitną tunikę. Tytuły szlacheckie przyznawano z pewnym - być może, niezamierzonym - poczuciem humoru: dworski almanach przekazuje informacje o niejakim Comte de Limonade i niejakim Duc de la Marmelade".

18 J. Pr i c e-M a r s, La Vocation de l'élite. Port-au-Prince 1919, s. 69.

19 Pełen tytuł zbioru opublikowanego w Paryżu w 1901 r. to Cric-Crac. Fables de La Fontaine racontées par un montagnard haïtien et transcrites en vers créoles (Trzask! Prask! Bajki La Fontaine'a opowiedziane przez górala haitańskiego i spisane po kreolsku). 
Price-Mars, w przeciwieństwie do Gaultiera, nie odnajduje w bowaryzmie żadnych pozytywnych cech. Żyje w środowisku zdominowanym przez ten rodzaj patologii i ponosi tego konsekwencje. Błędne koło przenikających się kultur prowadzi do sytuacji, w której twórca sam pada, w pewnym sensie, ofiarą bowaryzmu poprzez użycie terminu ,z importu” do scharakteryzowania rodzimego fenomenu ${ }^{20}$. Wydaje się jednak, że jest to wszechwystępujące zjawisko - podobnie jak pisanie w języku kolonizatora, tj. w angielskim, francuskim, hiszpańskim itp., w celu upowszechnienia teorii, popularyzacji kultury i dotarcia do większej liczby odbiorców ${ }^{21}$.

Zdaniem Price-Marsa, wyjściem z impasu byłoby pozbycie się ,pożyczonej duszy" (P-M 12), czyli, podobnie jak w przypadku Gaultiera i van Gennepa stworzenie na nowo tożsamości. Na jej ponowne odkrycie już bowiem za późno. Przytaczając ruch négritude, „murzyńskości” (powołany przez Aimé Césaire’a, Léona Damasa, Léopolda Sédara Senghora), pisarz podkreśla, że korzenie kultury haitańskiej tkwią w Afryce: „dziedzictwo jest w ośmiu dziesiątych darem Afryki” (P-M 222). Jedynie poprzez zrozumienie swojej „czarnej” tożsamości i świadomości Haitańczycy będą mogli uwolnić się od całkowitego wchłonięcia przez obcą kulturę. Rada Price-Marsa brzmi następująco:

zebrać elementy naszego życia społecznego, [...] określić gesty, zachowania naszego ludu, jakkolwiek pokorny by nie był, [...] p o ó w n a ć je z gestami i zachowaniami innych narodów, [...] zbadać ich źródło i usytuować je w życiu każdego człowieka na świecie. [P-M 12; podkreśl. Z. K.]

Z procesem porównywania - jako jednym z etapów przezwyciężania bowaryzmu zbiorowego - nie zgadza się pisarz i psychiatra martynikański, teoretyk dekolonizacji Frantz Fanon (1925-1961). Jego studium Peau noire, masques blancs (Czarna skóra, białe maski), które już w samym tytule nawiązuje do procesów identyfikacji i imitacji, skupia się na psychoanalitycznym ujęciu rasizmu oraz związków między człowiekiem białym a czarnym. Mimo że termin „bowaryzm zbiorowy" nie pada tu ani razu, śledząc tok rozumowania autora możemy zauważyć powszechne występowanie denotowanego tym terminem zjawiska na Martynice. Wyraża się ono głównie poprzez konflikt „,ja” z „Innym”. Fanon zaznacza, że ,czarni są porównaniem" (F 170) świata białego i czarnego oraz poszczególnych członków społeczności czarnej między sobą, ustawiczną analizą porównawczą ,ja"-,Inny”: w ten sposób wszystko sprowadza się do ciągłego podawania w wątpliwość własnej wartości.

W dyskusji nad zjawiskiem Fanon podkreśla powiązanie rasizmu z represją seksualności człowieka: stereotypowa kolokacja „,czarnego” z ,wulgarnym” i ,wyuzdanym" rodzi się w wyniku projekcji stłumionej seksualności białego na czarnego człowieka. Tym samym Fanon odrzuca tezę Carla G. Junga o wrodzonej nieświadomości zbiorowej: jego zdaniem, domniemana niższość rasowa nie jest elementem podświadomości, lecz została nabyta w trakcie jak najbardziej świadomego procesu.

Co więcej, również język uwidacznia aspekt ciągłego porównania. Posługi-

${ }^{20}$ Zob. J. M. A 11 a rd D u p la n t i e r, ,Nos frères d'autre-golfe”: Spiritualism, voudou and the mimetic literatures of Haiti and Louisiana. Louisiana 2006. Zob. też na stronie internetowej: http://etd.lsu.edu/docs/available/etd-11152006-152550/unrestricted/Duplantier_dis.pdf(data dostępu: $20 \times 2012$ ).

${ }^{21}$ Zob. W. B u r s z t a, Antropologia a literatura. „Teksty Drugie” 2005, nr 4, s. 50. 
wanie się wobec czarnoskórych mieszkańców tzw. petit nègre (małym czarnym), czyli językiem opartym na zdrobnieniach, błędach, intonacji typowej dla pogawędek z dziećmi, podkreśla poczucie wyższości. „Mówić w języku, to tyle co przyjąć świat, kulturę" (F 30). Biegłość we francuskim jest zaletą o ogromnym ładunku kulturowym, co potwierdza następujący przykład: o osobie władającej płynnie językiem Moliera powie się we Francji, że „mówi jak książka” (,il/elle parle comme un livre"); analogiczne określenie na Martynice to „parler comme un Blanc" - „mówić jak biały” (F 16).

Mali mieszkańcy Martyniki (pamiętajmy, że wyspa, która wcześniej była kolonią, w 1946 roku stała się regionem Francji, tzw. departamentem zamorskim) uczą się z tych samych podręczników, co ich paryscy koledzy, powtarzając wraz z nimi: „nasi przodkowie Galowie”. Tym samym identyfikują się z Europą, uważają się za Francuzów, a nie za Murzynów. Dla nich „,czarny żyje w Afryce” (F 120).

Dopiero w chwili bezpośredniego kontaktu z kulturą europejską, czyli w chwili przyjazdu do Francji, następuje proces „epidermizacji” (F 8), odkrycia innej twarzy-tożsamości, dotąd skrywanej pod maską. Okrzyk „Mamo, patrz, czarny, boję się!" (F 90) powoduje pierwszą traumę. Wraz z upływem czasu różnice pogłębiają się i narastają, dając początek kompleksowi niższości i fobiom. Tym samym Fanon nie zgadza się z Sigmundem Freudem: trauma nie pochodzi z okresu dzieciństwa, lecz wywołuje ją kontakt z rasistowską cywilizacją. Toteż nie ma racji Octave Mannoni twierdząc, iż psychika czarnoskórego usprawiedliwia kolonizację ${ }^{22}$. Dla Fanona sytuacja jest radykalnie odmienna: fakt, że człowiek czarny uznaje siebie za gorszego i podporządkowanego białemu, jest bezsprzecznie winą kolonizatora.

Taki sąd brzmi jak echo słów Jeana-Paula Sartre'a, który w swoich Rozważaniach o kwestii żydowskiej stwierdza: „Żyd to człowiek, którego inni ludzie uważają za Żyda - oto prawda elementarna, od której trzeba nam wyjść. [...] to antysemita tw or z y Żydów”23. Tak jak antysemityzm „tworzy Żydów” (czy, jak opisuje Simone de Beauvoir w Drugiej płci, mężczyzna oraz zewnętrzne czynniki kreują kobietę), podobnie rasizm tworzy Murzyna. Biała maska kultury i edukacji nie zmienia przynależności rasowej, nie hamuje okrzyku „Mamo, patrz, Murzyn, boję się!" Istnienie rasizmu, brak dialogu między kolonizatorem a skolonizowanym oraz niemożność współpracy utrzymują przy życiu bowaryzm zbiorowy.

W rozważaniach nad kulturą postkolonialną Edward W. Said stwierdza:

Pojęcie czarnej skóry w białej masce jest dokładnie tak mało użyteczne i nobilitujące w literaturoznawstwie, jak i w polityce. Naśladowanie i mimikra nie zaprowadzą nas daleko ${ }^{24}$.

Kolor skóry bądź język, którym się człowiek posługuje, nie może być podstawą jego dyskryminacji czy dominacji. „Nie ma czarnego. Ani białego” (F 187), sztuczny podział nie istnieje, nie należy ulegać bowarystycznemu pragnieniu naśladowania innych. „Wyższość? Niższość? Dlaczego nie spróbować po prostu dotknąć drugiego, usłyszeć, pokazać drugiego człowieka?" (F 187). Lepiej wierzyć własnym instynktom, podążać za własną kulturą, szanując, lecz nie ślepo naśladu-

22 O. M a n n o n i, Psychologie de la colonisation. Paris 1950.

${ }^{23}$ J.-P. S a rtr e, Rozważania o kwestii żydowskiej. Przeł. J. Li s o w s ki. Warszawa 1957, s. 65 . s. 361

${ }^{24}$ E. W. S a i d, Kultura i imperializm. Przeł. M. Wy r w a s - W i ś n i e w s k a. Kraków 2009, 
jąc obce zwyczaje i tradycje, choć jedyną drogą do odzyskania wolności, godności i świadomości narodowej pozostaje niezmiennie walka ${ }^{25}$.

Ani Frantz Fanon, ani Homi K. Bhabha nie nawiązują bezpośrednio do bowaryzmu zbiorowego jako takiego. Teoria mimikry hinduskiego badacza, opisywana na poziomie ogólnym, nie zaś w odniesieniu do konkretnej społeczności, wydaje się jednak bardzo podobna do fenomenu omówionego przez Gaultiera. Według Bhabhy to organizm kolonizacyjny wywołuje mimikrę: indywidualizacja każdego człowieka stanowi proces mimetyczny oparty na próbie naśladowania kogoś innego, bycia kimś innym. „Mimikra kolonialna to pragnienie zreformowanego, rozpoznawalnego Innego, ja k o p odmi otu różn ic y, który jest prawie taki sam, ale nie całkie m”26, jednak przy zachowaniu części samego siebie. W ten sposób tożsamość staje się mozaiką często sprzecznych (zważywszy na konflikt ,ja” z ,Innym”) interakcji, a mimikra - formą parodii kolonialnego autorytetu.

W przeciwieństwie do teorii masek Fanona ,Mimkra nie jest [...] maską ukrywającą jakąś obecność czy tożsamość [...]"27. Pod „białą maską" znajdujemy kolejne maski, ponieważ cała egzystencja opiera się na mimikrze pod przeróżnymi postaciami.

Kolonializm wymagał wykształcenia obywateli państw skolonializowanych oraz sformowania nowej grupy osób, która pomogłaby w rządzeniu krajem. Brytyjski historyk Thomas Babington Macaulay, analizując sytuację Indii w Minutes on Education, uznał wręcz za konieczne stworzenie ,klasy jednostek o hinduskiej krwi i kolorze skóry, ale angielskim guście, poglądach, obyczajach i intelekcie [...]"28. Tak więc mimikra, która staje się kontrowersyjnym sposobem na powołanie pośredników między kolonizatorem a skolonizowanymi (a tym samym między dwiema kulturami), stanowi również niebezpieczeństwo dla obu grup: kolonizator słabnie, zyskawszy rywala, jego naśladowcy zaś tracą własną tożsamość. Przedstawicieli tej nowej grupy wyraźnie nakreślił V. S. Naipaul w powieści The Mimic Men, której tytuł nieco niefortunnie przetłumaczono na polski jako Marionetki ${ }^{29}$ :

${ }_{25}$ Peau noire, masques blancs opublikowano 9 lat przed najgłośniejszym dziełem F. F a n on a z r. 1961 - Wyklętym ludem ziemi (Przeł. H. Ty g i e ls k a. Przedmowa E. R e kła j t i s. Posł. J. P. S a rtre. Warszawa 1985). Napisana po złożeniu przez autora dymisji z funkcji dyrektora szpitala psychiatrycznego w Algierii, po zetknięciu się z nieludzkim okrucieństwem francuskich władz wobec rdzennych Algierczyków, książka okazuje się o wiele silniejsza w wymowie od dzieła Fanona, bardziej brutalna i zdecydowana. W roku 1961 Fanon wie na pewno, że niemożliwe jest wyzwolenie się od kolonizatora bez użycia zdecydowanej siły, wręcz przemocy (Przemoc to zresztą tytuł pierwszego rozdziału tej książki - aktu oskarżenia). Peau noire, masques blancs zyskuje tym mocniejsze przesłanie, iż Fanon pisał tę książkę, wiedząc, że przegrał walkę ze śmiertelną chorobą, białaczką.

${ }^{26}$ H. K. B h a b h a, Mimikra i ludzie. O dwuznaczności dyskursu kolonialnego. Przeł. T. D ob r o g o s z c z. „Literatura na Świecie” 2008, nr 1/2, s. 185.

27 Ibidem, s. 189.

${ }^{28}$ Ibidem, s. 188.

${ }^{29}$ V. S. N a i p a u 1, Marionetki. Przeł. M. Z b o r o w s k a. Warszawa 2009. „Marionetki” to pacynki, lalki, narzędzie w czyichś rękach. ,Mimic men” to ludzie, którzy naśladują, imitują, kopiują zachowanie innych. J. J a r n i e w i c z na łamach „Gazety Wyborczej” z r. 2009 (nr z 10 III) skomentował to tak: „Ich [tj. dawnych kolonii] mieszkańcy to praktykanci mimikry, tytułowi Mimic Men, czyli »ślepi naśladowcy«, bo tak należałoby poprawnie przełożyć tytuł powieści Naipaula”. Inną propozycję przedstawia Dobrogoszcz w swoim thumaczeniu eseju Bhabhy Mimikra i ludzie: „ludzie-naśladowcy [...]” (s. 188), 
My, tu na wyspie, czytając książki wydrukowane w tamtym świecie, używając przedmiotów wyprodukowanych w tamtym świecie, byliśmy ludźmi opuszczonymi i zapomnianymi. Udawaliśmy, że istniejemy, że uczymy się, że przygotowujemy się do życia, my, marionetki Nowego Świata, a raczej małego nieznanego jego skrawka, już dotkniętego zgnilizną, szybko atakującą wszystkie tkanki ${ }^{30}$.

Na powieść składają się wspomnienia głównego bohatera, który zresztą bowarystycznie zmienia swoje imię z Ranjit Kripalsingh na pseudoangielskie Ralph R. K. Singh. Powracającym motywem jest tu wrak statku, metafora odzwierciedlająca świadomość utraty własnej tożsamości, bycia obcym dla siebie i dla reszty świata. Człowiek, który łatwo popada w imitację silniejszego od siebie modelu, dryfuje szukając bezpiecznego portu, który go przyjmie i „naprawi”: „dryfujący wrak, jak reagująca na bodźce zewnętrzne komórka, którą może zmienić przelotnie każde przygodne spotkanie" 31 .

Osłabienie tożsamości kolonizatora i skolonizowanego prowadzi do zatarcia różnic między nimi. Utrata czynnika różnicującego, jakim jest kolor skóry, tak upragniona przez Fanona, daje „ślepym naśladowcom” szansę na życie według własnych zasad i stawienie czoła dominacji imperium.

Dyskusja o bowaryzmie zbiorowym zaprowadziła nas daleko od szarej i deszczowej Normandii Emmy Bovary. Kiedy Émile Cailteaux, entuzjastyczny czytelnik, pisał w liście do Flauberta: „Kto wie [...], czy w niedługim czasie nie będziemy mówić o kobiecie niezrozumiałej, romantycznej, idealizującej: to jest b o vary, tak jak o fałszywym dewocie mówimy: to je st świ ęt os zek"32, nie podejrzewał zapewne, że któregoś dnia będą tak mówić nie tylko o pojedynczych istotach, ale o całych społecznościach zamieszkujących tereny Liberii, Haiti i Karaibów. Wszystko w naszej dyskusji zdaje się obracać wokół kontynentu afrykańskiego, jako starej kolonii bądź ojczyzny przodków mieszkańców innych krajów. Może zatem prawdziwie bowarystyczni są ci „Inni”, ucywilizowani kolonizatorzy, którzy zapomnieli, że historia homo sapiens zaczęła się właśnie w Afryce.

\section{Abstract}

ZUZANNA KRASNOPOLSKA

(University of Warsaw)

\section{MRS BOVARY IN THE TROPICS. \\ BOVARISM AS A (POST)COLONIAL PHENOMENON}

The article aims at analysing the collective bovarism in (post)colonial studies. The term "bovarism" was coined at the turn of $19^{\text {th }}$ and $20^{\text {th }} \mathrm{c}$. by Jules de Gaultier as one of the main assumptions of his idealistic philosophy. It refers to a man's innate ability to imagine oneself different from real, which can be manifested alike at individual and collective level. Thus, the collective bovarism, inseparably tied to the process of evolution, is characteristic of numerous societies all over the world. The article focuses on the discussions about the various approaches to the collective bovarism as based on the analysis of the texts by Arnold van Gennep, who researched it in Liberians, Jean Price-Mars (in Haitians), Frantz Fanon (in Martinicans), as well as on discerning the similarities between the collective bovarism and Homi K. Bhabha's theory of mimicry.

\footnotetext{
${ }^{30} \mathrm{~N}$ a i p a u 1, op. cit., s. 210.

31 Ibidem, s. 40.

${ }^{32}$ G. F 1 a u be r t, Correspondance 1851-1858. Red. J. B r u n e a u. T. 2. Paris 1980, s. 1382.
} 